\title{
Detection and molecular characterization of Egyptian isolates of grapevine viruses
}

\author{
F. FATTOUH ${ }^{2}$, C. RATTI ${ }^{1}$, A. M. D. EL AHWANY², E. ABDEL ALEEM ${ }^{2}$, A. R. BABINI ${ }^{3}$, C. RUBIES AUTONELL ${ }^{1}$
}

${ }^{1}$ DiSTA - Patologia Vegetale, Università di Bologna, Viale G. Fanin, 40 - 40127 Bologna, Italy; ${ }^{2}$ Botany and Microbiology Department Faculty of Science Alexandria University, Alexandria, Egypt; ${ }^{3}$ Servizio Fitosanitario Regionale, Regione Emilia Romagna, Bologna, Italy

\begin{abstract}
Summary. - Selected commercial and/or local vineyards and nurseries in three different governorates of Egypt (Alexandria, El-Beheira and El-Menofia) were surveyed for symptoms indicative of infection by grapevine viruses. Leaf samples from red-fruited and white-fruited Vitis vinefera were tested for grapevine leafroll associated viruses (GLRaV-1, GLRaV-2, and GLRaV-3), grapevine viruses A and B (GVA, GVB), grapevine rupestris stem pitting virus (GRSPaV), grapevine fanleaf virus (GFLV), and grapevine fleck virus (GFKV) from early April to late October 2010. Incidence of these viruses was assessed by RT-PCR in 60 different samples. Selected amplicons were sequenced. While GVA was the most wide spread (30\%), GLRaV-1, GVB, GFLV, and GFKV were not detected during the survey. However, GVA, GLRaV-2, GLRaV-3, and GRSPaV were detected in the form of single infection or in mixed infections of 2 to 4 viruses. Phylogenetic analysis was performed on all Egyptian isolates of GLRaV-2 (4), GLRaV-3 (7), GVA (3), and GRSPaV (6). GRSPaV was detected for the first time in Egypt. Phylogenetic analysis provided insights into the evolutionary relationship between the reported Egyptian isolates and other previously reported isolates.
\end{abstract}

Keywords: Egypt; grapevine viruses; ELISA; RT-PCR; detection; sequence analysis

\section{Introduction}

Grapevine (Vitis spp.) is economically one of the most important cultivated fruit species in the world, is one of the oldest horticultural crops widely grown in temperate climates and represents a highly valuable agricultural commodity (Engel et al., 2010).

In Egypt, grapevine (Vitis vinefera) is of great importance and plays an important role in agricultural economy; the annual production is 1.1 million tones of mainly table grapes and dried fruit (Youssef et al., 2009). With an area of about 62,000 ha, which yielded 1,104,000 tons in 2004,

E-mail: faiza_fattouh@yahoo.com; phone: (+2)-01221151259. Abbreviations: GFLV = grapevine fanleaf virus; GFKV = grapevine fleck virus; GLRaV-1, GLRaV-2, and GLRaV-3 = grapevine leafroll associated viruses; GRSPaV = grapevine rupestris stem pitting virus; GVA, GVB = grapevine viruses $\mathrm{A}$ and $\mathrm{B}$; HSP70 gene $=$ heat shock protein 70 gene; $\mathrm{LRD}=$ leaf roll disease and the total area of production of approximately 65,000 ha in 2005, the grapevine ( $V$. vinifera) ranks second among the fruit crops of Egypt (Ahmed et al., 2004; Youssef et al., 2009; Fayek et al., 2009). Vineyards are concentrated along the Nile valley and in recently reclaimed desert land. The most important governorates cultivating grapes are BeniSwef, El-Beheira, Giza, Minofia, and Qualubia (Youssef et al., 2007). Table-grape cultivars are the most widely grown, with a prevalence of the traditional local cultivars (Banaty Abiad and Romy Ahmer), although a significant introduction of foreign cultivars, mainly seedless (Fantasy, Flame, King's Ruby and Superior), has taken place in recent years. There are more than 70 infectious agents including viruses, viroids and phytoplasmas that have been reported in grapevines. Among them, at least 58 are viral pathogens, some with extremely high incidences (Martelli and Boudon-Padieu, 2006). Some important virus diseases are caused by GFLV, GFkV, GVA, GVB, and grapevine leafroll-associated viruses. ELISA method can be used for testing multiple plants for 
a single virus using one well per plant sample, or alternatively a single plant can be simultaneously tested for many viruses on a single plate with different antibodies coated to each well in duplicate or triplicate for reproducibility (Craig et al., 2004). PCR technology permits the detection of viruses at the levels several orders of magnitude lower than is possible by other methods. This high sensitivity facilitates virus detection during early stages of infection of plants, in soil and in their vector samples (Fenby et al., 1995). RT-PCR is a very sensitive and reliable molecular methodology, which has been developed and used for the detection of many plant RNA viruses (Rowhani et al., 2005). In this study, we developed RT-PCR detection methodology for the detection of GLRaV-1, GLRaV-2, GLRaV-3, GVA, GVB, GRSPaV, GFLV, and GFKV, in addition to partial sequence characterization of the Egyptian isolates of the detected viruses.

\section{Materials and Methods}

Field surveys. A survey and collection of samples from different commercial or local vineyards and nurseries in different selected governorates of Egypt, namely Alexandria, El-Beheira, and El-Menofia, representing old and recently reclaimed land, was conducted during the period between early April and late October 2010. Survey was for the detection and assessment of the incidence of major grapevine viruses: GVA, GVB, (GLRaV-1, -2 and -3), GRSPaV, GFLV, and GFKV. Leaf samples, including the petioles and midribs showing various types of virus and viruslike symptoms related to leafroll disease symptoms (LRD) were collected for laboratory testing. A total of $60 \mathrm{~V}$. vinifera samples, representing cultivars Flame seedless (red-fruited cultivar), Thompson seedless and Superior (white-fruited cultivars), and rootstocks (Freedom) were collected. All samples were labeled, wrapped in plastic bag and stored at $+4^{\circ} \mathrm{C}$ until use for laboratory analysis after the collection time (April to late October). Detection was performed on two levels: symptomatology and molecular identification.

Preparation of total RNA extracts. Total RNA was extracted from leaf samples using ILLUSTRA RNAspin Mini RNA isolation kit (GE Healthcare, UK), according to the manufacturer's instructions and the procedure was as described by MacKenzie et al. (1997). The total RNA was stored at $-20^{\circ} \mathrm{C}$ for one day.

RT-PCR analyses. For the synthesis of the first-strand cDNA of all detected grapevine viruses, $1 \mu \mathrm{l}$ total RNA was added to $4 \mu \mathrm{l}$ reverse transcriptase mix containing 1x M-MLV buffer (Promega), $0.5 \mu \mathrm{g}$ random primer (Roche), $1 \mathrm{mmol} / \mathrm{l} \mathrm{dNTP} \operatorname{mix}$ (Promega) and 50U M-MLV reverse transcriptase (Promega). The mixture was incubated at $42^{\circ} \mathrm{C}$ for $1 \mathrm{hr}$, then at $70^{\circ} \mathrm{C}$ for $10 \mathrm{~min}$, and held at $+4^{\circ} \mathrm{C}$ in the PCR thermocycler (Gene Amp 9700 thermocycler, Applied Biosystem ABI, USA). cDNA was amplified by PCR in a reaction mixture ( $25 \mu \mathrm{l}$ final volume) containing $1 \mathrm{x}$ Mg-free Buffer (Promega), $2 \mathrm{mmol} / \mathrm{l} \mathrm{MgCl}_{2}$ (Promega), $5 \mathrm{pmol}$ of each primer, $0.2 \mathrm{mmol} / \mathrm{l} \mathrm{dNTP} \operatorname{mix}$ (Promega), $1.25 \mathrm{U}$ thermostable Taq DNA polymerase (Promega) and $5 \mu$ of the RT mixture. The list of viruses, primers used, region amplified, expected product size and reference for RT-PCR used to detect grapevine viruses under investigation are shown in Table 1. Thermal cycling conditions tested for the optimization of PCR for the detection of grapevine viruses are shown in Table 2.

Table 1. RT-PCR primers used for detection of grapevine viruses

\begin{tabular}{|c|c|c|c|c|c|}
\hline Virus & Primer name & Primer sequence $\left(5^{\prime}-3^{\prime}\right)$ & Region amplified & $\begin{array}{c}\text { Expected } \\
\text { product size } \\
\text { (bp) }\end{array}$ & Reference \\
\hline \multirow[t]{2}{*}{ GVA } & GVA659 1F & GAGGTAGATATAGTAGGACCTA & \multirow{2}{*}{$\begin{array}{l}\text { Coat protein } \\
(\mathrm{ORF} 4)\end{array}$} & \multirow[t]{2}{*}{271} & \multirow{2}{*}{$\begin{array}{l}\text { Goszczynski and Jooste } \\
(2003)\end{array}$} \\
\hline & GVA686 2R & TCGAACATAACCTGTGGCTC & & & \\
\hline \multirow[t]{2}{*}{ GVB } & $\mathrm{H} 28$ & GTGCTAAGAACGTCTTCACAGC & \multirow{2}{*}{$\begin{array}{l}\text { Coat protein-RNA bind- } \\
\text { ing protein-like (ORF5) }\end{array}$} & \multirow[t]{2}{*}{459} & \multirow{2}{*}{$\begin{array}{l}\text { Minafra and Hadidi } \\
(1994)\end{array}$} \\
\hline & $\mathrm{C} 410$ & ATCAGCAAACACGCTTGAACCG & & & \\
\hline \multirow[t]{2}{*}{ GLRaV-1 } & HSP70-149f & ACCTGGTTGAACGAGATCGCTT & \multirow{2}{*}{$\begin{array}{l}\text { Heat shock protein } 70 \text { - } \\
\text { like protein (ORF3) }\end{array}$} & \multirow[t]{2}{*}{168} & \multirow[t]{2}{*}{ Osman et al. (2007) } \\
\hline & HSP70-293r & GTAAACGGGTGTTCTTCAATTCTCT & & & \\
\hline \multirow[t]{2}{*}{ GLRaV-2 } & P19qtF4 & CTAACAATTTCTTCTTTGGATCGCAT & \multirow[t]{2}{*}{ ORF7-ORF8 } & \multirow[t]{2}{*}{202} & \multirow[t]{2}{*}{ Beuve et al. (2007) } \\
\hline & P24qtR & AGAATGTCTTCAGCTTCATAAGGAG & & & \\
\hline \multirow[t]{2}{*}{ GLRaV-3 } & $56 \mathrm{~F}$ & AAGTGCTCTAGTTAAGGTCAGGAGTGA & \multirow{2}{*}{$\begin{array}{l}\text { Heat shock protein } 70 \text { - } \\
\text { like protein (ORF4) }\end{array}$} & \multirow[t]{2}{*}{254} & \multirow[t]{2}{*}{ Osman et al. (2007) } \\
\hline & $285 \mathrm{R}$ & GTATTGGACTACCTTTCGGGAAAAT & & & \\
\hline \multirow[t]{2}{*}{ GFLV } & M2 & (C/T)T(A/G)GATTTTAGGCTCAATGG & \multirow[t]{2}{*}{ Movement protein } & \multirow[t]{2}{*}{290} & \multirow[t]{2}{*}{ Wetzel et al. (2002) } \\
\hline & M3 & TG(C/T)AA(A/G)CCAGG(A/G)AAGAAAAT & & & \\
\hline \multirow[t]{2}{*}{ GFKV } & $\mathrm{FkV} 1$ & AGTACCTCCTCCACCGCACC & \multirow{2}{*}{$\begin{array}{l}\text { Replicase } \\
\text { (ORF1) }\end{array}$} & \multirow[t]{2}{*}{243} & \multirow{2}{*}{$\begin{array}{l}\text { Sabanadzovic et al. } \\
(1996)\end{array}$} \\
\hline & FkV2 & TTTCTTCGGGCAGAGAGCCGTCC & & & \\
\hline \multirow[t]{2}{*}{ GRSPaV } & RSP35 & $\begin{array}{l}\text { AG(A/G)(C/T)TTAG(A/G)GT(A/G)GCTAA } \\
(\mathrm{A} / \mathrm{G}) \mathrm{GC}\end{array}$ & \multirow[t]{2}{*}{$\begin{array}{l}\text { RNA-dependent RNA } \\
\text { polymerase (ORF1) }\end{array}$} & \multirow[t]{2}{*}{476} & \multirow[t]{2}{*}{ Lunden et al. (2010) } \\
\hline & RSP36 & CACAT(A/G)TCATG(A/C/G)CC(C/T)GCAAA & & & \\
\hline
\end{tabular}


Table 2. Thermal cycling conditions tested for the optimization of PCR for the detection of grapevine viruses

\begin{tabular}{|c|c|c|c|c|c|c|}
\hline Primer name & $\begin{array}{l}\text { Initial denaturation } \\
\text { step }\end{array}$ & Number of cycles & Denaturation step & Annealing step & Elongation step & $\begin{array}{c}\text { Final extension } \\
\text { step }\end{array}$ \\
\hline GVA659 1F/ 686 2R & $94^{\circ} \mathrm{C} / 5 \mathrm{~min}$ & 30 & $94^{\circ} \mathrm{C} / 10 \mathrm{~s}$ & $56^{\circ} \mathrm{C} / 10 \mathrm{~s}$ & $72^{\circ} \mathrm{C} / 30 \mathrm{~s}$ & $72^{\circ} \mathrm{C} / 10 \mathrm{~min}$ \\
\hline $\mathrm{H} 28 / \mathrm{C} 410$ & $94^{\circ} \mathrm{C} / 5 \mathrm{~min}$ & 35 & $94^{\circ} \mathrm{C} / 10 \mathrm{~s}$ & $54^{\circ} \mathrm{C} / 10 \mathrm{~s}$ & $72^{\circ} \mathrm{C} / 45 \mathrm{~s}$ & $72^{\circ} \mathrm{C} / 10 \mathrm{~min}$ \\
\hline LR1HSP70-149f/293r & $94^{\circ} \mathrm{C} / 5 \mathrm{~min}$ & 30 & $94^{\circ} \mathrm{C} / 10 \mathrm{~s}$ & $59^{\circ} \mathrm{C} / 10 \mathrm{~s}$ & $72^{\circ} \mathrm{C} / 10 \mathrm{~s}$ & $72^{\circ} \mathrm{C} / 10 \mathrm{~min}$ \\
\hline P19qtF4/ P24qtR & $94^{\circ} \mathrm{C} / 5 \mathrm{~min}$ & 35 & $94^{\circ} \mathrm{C} / 10 \mathrm{~s}$ & $54^{\circ} \mathrm{C} / 10 \mathrm{~s}$ & $72^{\circ} \mathrm{C} / 45 \mathrm{~s}$ & $72^{\circ} \mathrm{C} / 10 \mathrm{~min}$ \\
\hline $56 \mathrm{~F} / 285 \mathrm{R}$ & $94^{\circ} \mathrm{C} / 5 \mathrm{~min}$ & 30 & $94^{\circ} \mathrm{C} / 10 \mathrm{~s}$ & $59^{\circ} \mathrm{C} / 10 \mathrm{~s}$ & $72^{\circ} \mathrm{C} / 10 \mathrm{~s}$ & $72^{\circ} \mathrm{C} / 10 \mathrm{~min}$ \\
\hline M2/ M3 & $94^{\circ} \mathrm{C} / 5 \mathrm{~min}$ & 35 & $94^{\circ} \mathrm{C} / 10 \mathrm{~s}$ & $52^{\circ} \mathrm{C} / 10 \mathrm{~s}$ & $72^{\circ} \mathrm{C} / 30 \mathrm{~s}$ & $72^{\circ} \mathrm{C} / 10 \mathrm{~min}$ \\
\hline FkV1/FkV2 & $94^{\circ} \mathrm{C} / 5 \mathrm{~min}$ & 35 & $94^{\circ} \mathrm{C} / 10 \mathrm{~s}$ & $54^{\circ} \mathrm{C} / 10 \mathrm{~s}$ & $72^{\circ} \mathrm{C} / 45 \mathrm{~s}$ & $72^{\circ} \mathrm{C} / 7 \mathrm{~min}$ \\
\hline RSP35/ RSP36 & $94^{\circ} \mathrm{C} / 5 \mathrm{~min}$ & 35 & $94^{\circ} \mathrm{C} / 10 \mathrm{~s}$ & $54^{\circ} \mathrm{C} / 10 \mathrm{~s}$ & $72^{\circ} \mathrm{C} / 45 \mathrm{~s}$ & $72^{\circ} \mathrm{C} / 7 \mathrm{~min}$ \\
\hline
\end{tabular}

The PCR products $(10 \mu \mathrm{l})$ were analysed by gel electrophoresis on a $1.2 \%$ agarose gel and visualized on a UV-transilluminator after staining with ethidium bromide. The $1 \mathrm{~Kb}$ DNA ladder (Promega) was included to determine the size of amplified products.

Cloning, sequencing and phylogenetic analyses. The RT-PCR products were purified according to manufacturer's instructions using Wizard SV Gel and Clean-Up System Kit (Promega, USA), ligated into pGEM-T Easy vector (Promega) and transformed into Escherichia coli strain M1022 (Promega). Recombinant plasmids containing inserts of the expected size, identified by direct PCR amplification, were purified using a Wizard plus SV miniprep kit (Promega). The identity of the plasmid insert was verified by sequencing (MWG-Biotech AG, Germany) and the sequences obtained were submitted to GenBank. Computer-based comparison of partial nucleotide sequences of the Egyptian isolates of viruses to that of other geographical isolates present in GenBank, by multiple sequence alignments, were generated using Workbench version 3.2, CLUSTALW program (Thompson et al., 1994). Phylogenetic and molecular evolutionary analyses were conducted using MEGA version 4 (Bootstrap test of phylogeny (1000 replicates), NeighorJoining method) (Tamura et al., 2007).

\section{Results}

\section{Virus symptoms observed in vineyards}

During the period of the survey, only leafroll disease symptoms, in the form of typical leaf symptoms including cupping and reddening of leaves between major veins in red-fruited $V$. vinifera cultivars and cupping and a slight chlorosis of leaves between major veins in white-fruited $V$. vinifera cultivars, were observed by visual inspection. A low field incidence of leaf roll symptoms was observed among vineyards as assessed by visual inspection. Characteristic symptoms of other grapevine viruses were not observed in visited vineyards during the survey. Symptoms were manifested in the margins of upper leaves, which were rolled, and by leaves turning dark yellow with green main veins (Fig. 1a and b). In red-fruited $V$. vinifera cultivars, the leaf blades turned into bright red and leaf margins rolled downward. Symptoms were also manifested in the margins of upper leaves, which were rolled, and by leaves turning dark red with green main veins (Fig. 1c). Leaf roll disease causes also significant losses and delays in fruit ripening (Fig. 1d). The major observation in the survey was that heavy infestations of unidentified mealybugs were common in most of the surveyed vineyards.

\section{RT-PCR for detection of grapevine viruses}

A total of 60 symptomatic samples were processed by RT-PCR for the detection of grapevine viruses (GLRaV-1, GLRaV-2, GLRaV-3, GVA, GVB, GRSPaV, GFLV, and GFKV). Results indicated that the overall infection in the surveyed Egyptian grapevines was $46.6 \%$ (28 out of 60 ). $20 \%$ of the samples were infected with one virus and $26.6 \%$ were infected with more than one virus (mixed infection). GVA was the most widespread virus (30\%). GLRaV-3 (28.8\%), GRSPaV (16.6\%), and GLRaV-2 (10\%) were also detected during the survey, while GLRaV-1, GVB, GFLV, and GFKV were not detected in any of the samples tested.

Grapevine viruses GVA, GLRaV-2, GLRaV-3, and GRSPaV were found individually and in various combinations as shown in Table 3. The highest incidence was recorded in El-Menofia (50\%), followed by El-Beheira (El-Nobaria) (35.7\%). The sanitary status of native Egyptian cultivar Thompson seedless (92.8\%) was poorer than that of imported cultivars Superior and Flame seedless (35.8\%).

\section{Partial sequencing of the Egyptian isolates clones of} viruses

DNA products of the expected size were obtained from the total RNA from grapevine leaves infected with GLRaV-2 (202 bp), GLRaV-3 (254 bp), GVA (271), and GRSPaV (476 bp). No viral DNA amplicon was obtained from the total 
(a)

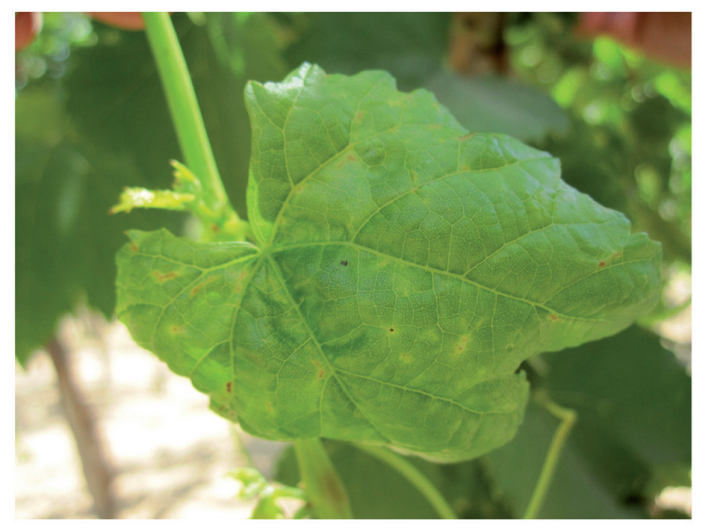

(c)

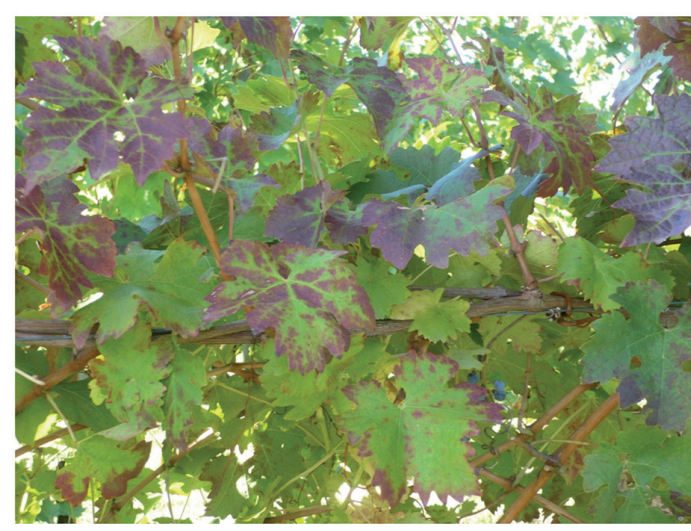

(b)

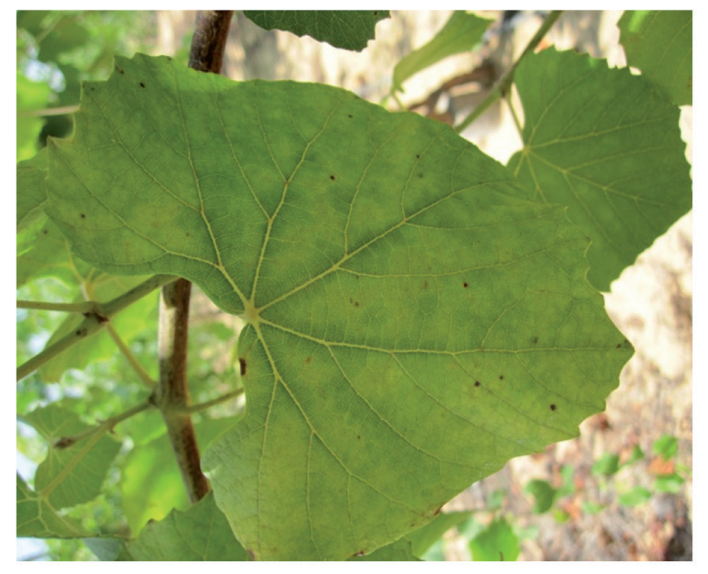

(d)

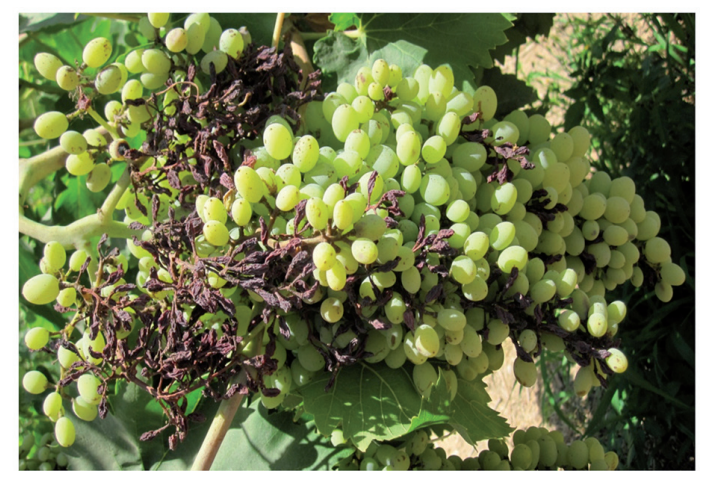

Fig. 1

Suspected leafroll disease symptoms in selected vineyards in different governorates of Egypt from early April to late October 2010 In white-fruited V. vinifera cultivars cupping and a slight chlorosis of leaves between major veins (a, b). In red-fruited Vitis vinifera cultivars cupping and reddening of leaves between major veins, while main veins remain green (c). Loss, delay and variation in fruit ripening (d).

Table 3. Distribution of viral infection (individually or in various combinations)

\begin{tabular}{lc}
\hline Individual infection & \\
\hline Viral type & Percentage of detection \\
\hline GVA & $10 \%$ \\
GLRaV-3 & $5 \%$ \\
GRSPaV & $3.3 \%$ \\
GLRaV-2 & $1.6 \%$ \\
\hline Various viral combinations & \\
\hline Double infection & $10 \%$ \\
\hline GVA and GLRaV-3 & $1.6 \%$ \\
GVA and GLRaV-2 & $1.6 \%$ \\
GRSPaV and GLRaV-3 & $5 \%$ \\
\hline Triple infection & $1.6 \%$ \\
\hline GRSPaV, GLRaV-2 and GLRaV-3 & $1.6 \%$ \\
GVA, GRSPaV and GLRaV-3 & Percentage of detection \\
GVA, GLRaV-2 and GLRaV-3 & $3.3 \%$ \\
\hline Quaternary infection & \\
\hline GRSPaV, GVA, GLRaV-2 and & Percentage of detection \\
\hline GLRaV-3 &
\end{tabular}

RNA from healthy vine leaves. DNA amplicons obtained by RT-PCR for all isolates of GVA, GLRaV-2, GLRaV-3, and GRSPaV were each cloned and sequenced. Nucleic acid sequences ( 3 of GVA, 4 of GLRaV-2, 7 of GLRaV-3, and 6 for GRSPaV) determined in this study were made available in GenBank as accession numbers JN688279 to JN688285 for GLRaV-3, JN700905 to JN700908 for GLRaV-2, JN683368 to JN683370 for GVA and JN688271 to JN688276 for GRSPaV. Sequence analysis confirmed the respective viral nature of RT-PCR products.

RT-PCR amplification of different amplicons allowed partial sequences and phylogenetic analysis of different isolates of GLRaV-3 (7), GLRaV-2 (4), GVA (3), and GRSPaV (6). Comparative analysis indicated low to moderate nucleotide sequence identities in the GLRaV-3 heat shock 70 homologue gene (74\% to $90 \%$ ), GLRaV-2 ORF7 and ORF8 protein gene (75\% to 97\%), GVA coat protein gene (70\% to 91\%), GRSPaV RNA-dependent RNA polymerase gene ( $72 \%$ to $93 \%$ ) when compared to corresponding virus reference strains previously reported. 

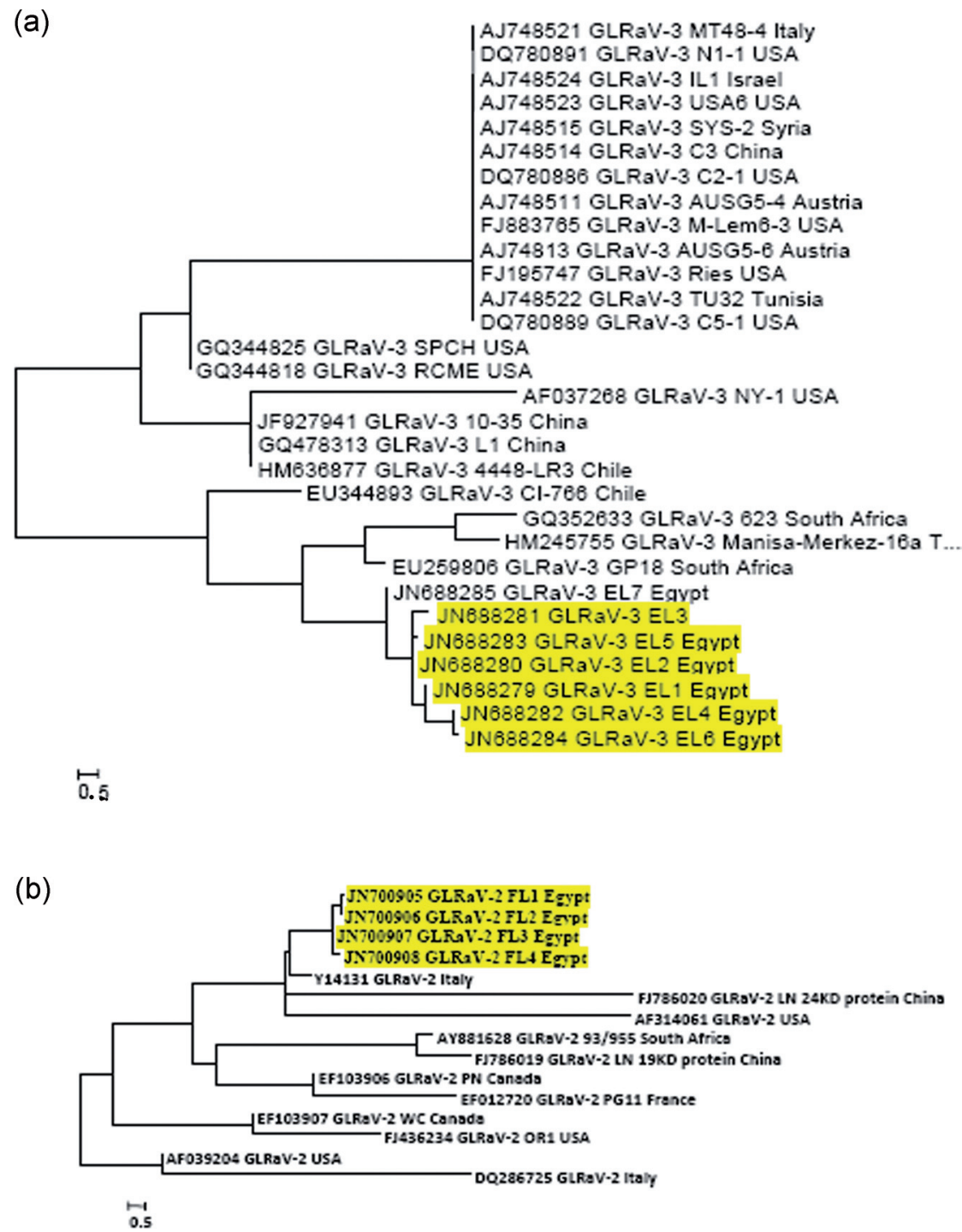

Fig. 2

Phylogenetic trees reconstructed from partial nucleotide sequences of (a) HSP70h gene of grapevine leafroll-associated virus 3 (GLRaV-3) and (b) ORF7 and ORF8 protein gene of grapevine leafroll-associated virus 2 (GLRaV-2) isolates by the neighbor-joining method of MEGA4 Tamura et al. (2007)

Bootstrap analysis was performed with 1000 replicates. The scale bar shows the number of substitutions per nucleotide.

Comparison of partial nucleotide sequences of the Egyptian isolates of grapevine viruses with that of other reported isolates

Phylogenetic relationships among viral isolates were determined for a 254-nt fragment of the GLRaV-3 HSP70h gene, a 202-nt fragment of the GLRaV-2 ORF7 and ORF8 protein gene, a 271-nt fragment of the GVA CP gene, and a 476-nt fragment of the GRSPaV RdRp gene.

The comparison of the HSP70h gene of GLRaV-3 showed that nucleotide sequence identities ranged from $88 \%$ to $99 \%$ between seven Egyptian isolates (JN688279 to JN688285). Phylogenetic analyses revealed that our 7 Egyptian GLRaV-3 isolates had a distant relationship with other isolates and fell into one clade. The next-closest isolate was GP18 isolate from South Africa (EU259806) as shown in Fig. 2a. This might be an indication that the Egyptian isolates are distinct from other GLRaV-3 isolates reported earlier. Comparison of GLRaV-2 sequences showed that identities of nucleotides between the four Egyptian isolates and other reported isolates were $75 \%$ to $97 \%$. Phylogenetic analyses revealed that our 4 Egyptian GLRaV-2 isolates grouped together in the same 
(a)

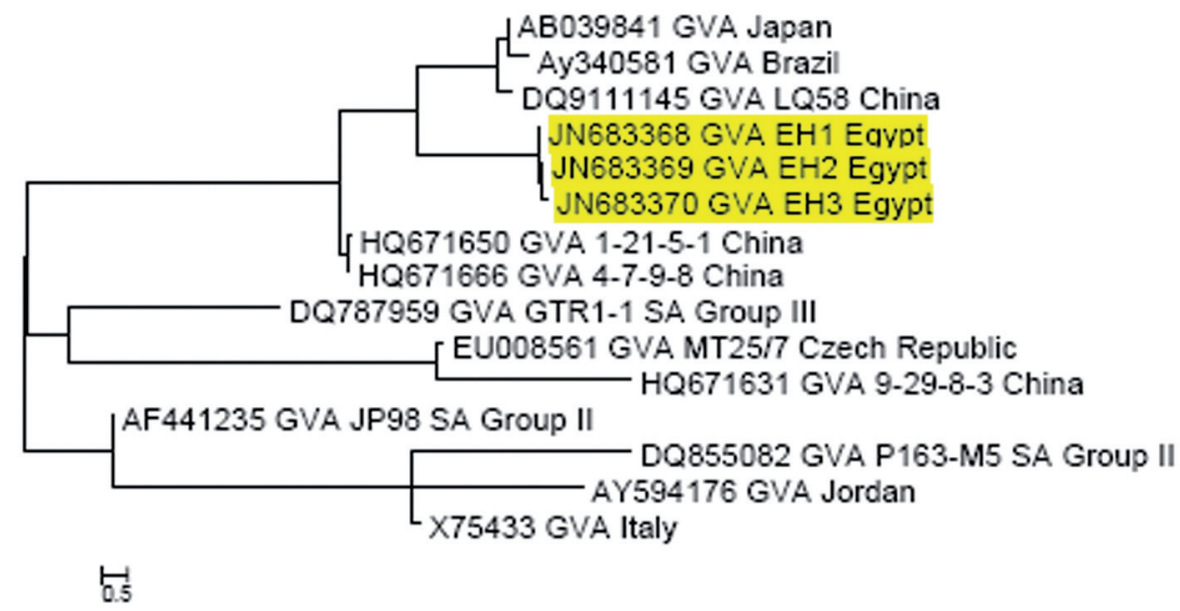

(b)
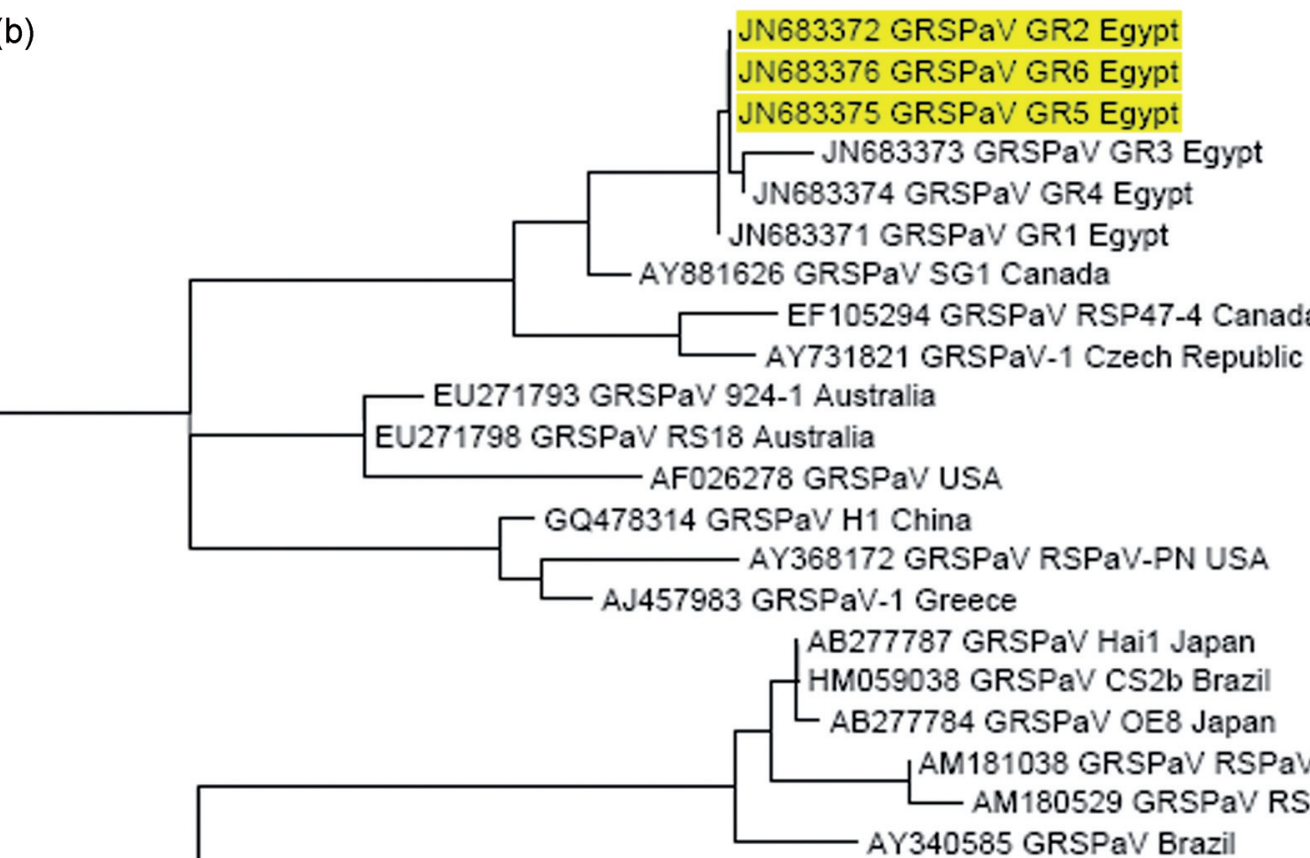

AB277787 GRSPaV Hai1 Japan

HM059038 GRSPaV CS2b Brazil

AB277784 GRSPaV OE8 Japan

AM181038 GRSPaV RSPaV-CH-S4G USA

-AM180529 GRSPaV RSPaV-PN-52 USA.

AY340585 GRSPaV Brazil

EU247951 GRSPaV 61.22F.N.SY.SA (South...

AF057136 GRSPaV-1 USA

DQ864489 GRSPaV SH3.4 South Africa

FJ884333 99B.SdZ5.3 South Africa

FN555301 GRSPaV P Italy

- AY368590 strain Syrah USA

FR691076 GRSPaV-MG Italy

AY881627 GRSPaV BS Canada

$\stackrel{-1}{0.5}$

Fig. 3

Phylogenetic trees reconstructed from partial nucleotide sequences of (a) CP gene of grapevine virus A (GVA), and (b)RdRp gene of grapevine rupestris stem pitting virus (GRSPaV) isolates by the neighbor-joining method of MEGA4 Tamura et al. (2007)

Bootstrap analysis was performed with 1000 replicates. The scale bar shows the number of substitutions per nucleotide. 
branch and appear to be closely related. The next-closest isolate was an Italian isolate (Y14131) as shown in Fig. 2b.

Sequence analysis of CP gene of GVA showed nucleotides identities ranging from $90 \%$ to $96 \%$ between three Egyptian isolates (JN683368 to JN683370). Phylogenetic analyses revealed that the three Egyptian GVA isolates had a distant relationship with other isolates, fell into one clade and appear to be closely related. The next-closest isolate was LQ58 isolate from China (DQ9111145) as shown in Fig. 3a. The sequence analysis of RdRp gene of GRSPaV, showed nucleotides identities ranging from $87 \%$ to $99 \%$ between six Egyptian isolates (JN688271 to JN688276). Phylogenetic analyses revealed that our 6 Egyptian GRSPaV isolates had a distant relationship with other isolates and grouped together in the same branch. The next-closest isolate was SG1 isolate from Canada (AY881626) as shown in Fig. 3b. It should be noted that geographical location-associated clustering of Egyptian GLRaV-2, GLRaV-3, GVA, and GRSPaV isolates was observed.

\section{Discussion}

In Egypt, grapevine ( $V$. vinifera) is an economically important crop in agricultural economy (Youssef et al. 2009). Surveyed area covered commercial or local vineyards and nurseries in Alexandria, El Beheira (El Nobaria) and ElMenofia, representing old and recently reclaimed desert land. The only symptoms observed and identified with reasonable confidence in the field were those of leafroll disease, in both red and white-berried $V$. vinifera cultivars, which consist of typical leaf symptoms including cupping and reddening of leaves between major veins in red-berried $V$. vinifera cultivar (Flame Seedless) and cupping and chlorosis of leaves between major veins in white-berried $V$. vinifera cultivars (Thompson seedless and Superior). This is in contrast to previous reports by Ahmed et al. (2004) on the presence of symptoms only on red-berried cultivars and by Salem et al. (2007) on absence of leafroll symptoms and presence of symptoms associated with GFLV and GVA. Heavy infestations of unidentified mealybugs were common in most of the surveyed vineyards, similar to previous report by Ahmed et al. (2004). Based on previous reports, the detection of viral infection was dedicated to viruses GLRaV-1, GLRaV-2, GLRaV-3, GFLV, GFKV, GRSPaV, GVA, and GVB.

Several different methods such as biological indexing (Ahmed et al., 2004; Salem et al., 2007), serological assays (ELISA) (Lunden et al., 2010) and/or molecular assays (RT-PCR, multiplex PCR and real time PCR) (Gambino and Gribaudo, 2006; Osman et al., 2008; Wang et al., 2011) were previously used for detecting grape vine viruses. Our study for virus identification was, however, based solely on their detection by RT-PCR using virus-specific prim- ers. Several studies have confirmed the efficiency of this technique for detection of grapevine viruses (Youssef et al., 2007; Eichmeier et al., 2011). With the use of RT-PCR for the identification of infection in 60 samples, an overall viral infection was identified in $46.6 \%$ of samples (28 out of 60 ). $20 \%$ of the samples were infected with one virus and $26.6 \%$ were infected with more than one virus (mixed infection). The most widespread virus in our survey was GVA (30\%) followed by GLRaV-3 (28.8\%), GRSPaV (16.6\%) and GLRaV-2 (10\%). GLRaV-1, GVB, GFLV, and GFKV were not detected. Prevalence of GLRaV-2, GLRaV-3, and GVA virus infection was in El Menofia governorate. The low sanitary status of the sampled areas correlated with higher incidence of the virus. However, prevalence of GRSPaV was in El Beheira governorate. The highest incidence was recorded in El-Menofia (old land) (50\%), followed by El-Beheira (El-Nobaria) (new land) $(35.7 \%)$. This is lower incidence than that previously reported for grapevine viruses in Egypt and in other Mediterranean countries (Digiaro et al., 2000; Ahmed et al., 2004). Despite the high incidence of GLRaV-3 and the presence of GLRaV-2, a low field incidence of leafroll symptoms was observed. This is possibly because most native Egyptian cultivars are white-berried table grapes that show mild or unapparent symptoms. This is in agreement with previous reports, which indicated that GLRD symptoms in whiteberried cultivars are less striking, with mild to no chlorosis in the interveinal areas (Rayapati et al., 2008; Jarugula et al., 2010). The self-rooted condition of Egyptian vineyards accounts for the apparent absence of rugose wood symptoms in the field, notwithstanding the very high incidence of GVA (the putative agent of Kober stem grooving) and the presence of GRSPaV (the agent of rupestris stem pitting, RSP), two of the diseases of the rugose wood complex (Martelli and Boudon-Padieu, 2006). Rugose wood is a disease of the scion/graft combination, thus infection is latent in ungrafted scions and rootstocks, but symptoms develop after grafting (Martelli and Boudon-Padieu, 2006). Also, it was reported that some variants of GRSPaV are latent in $V$. vinifera cultivars (Alabi et al., 2010). It should be stressed that heavy widespread mealybug infestations are a major threat to the Egyptian viticultural industry. These are the basis for equally widespread occurrence of GVA and GLRaV-3 in traditional vineyards, and also contaminate newly introduced planting material. Indications of an apparent total absence of GFLV and GFKV in our study show that both viruses may have had little chance to spread, as native grapevine germplasm is likely to have been essentially healthy since the very beginning of cultivation, and own-rooted nature of Egyptian vineyards has favored the preservation of a healthy status by avoiding the contamination that so very frequently occurs in nurseries. In addition to the GFLV, its nematode vectors Xiphinema index may not be present in our country. The presented results are in agreement with previous report by 
Ahmed et al. (2004) on the absence of GFKV and scarce presence of GFKV. Our results are in contrast with previous reports on presence of GFLV in Egypt and GFKV, which occurs at high rates in countries in Mediterranean region (Tolba and El-Kady, 1991; Digiaro et al., 2000; Darwish, 2005; Fiore et al., 2008; Fayek et al., 2009; Youssef et al., 2009).

Analyses of partial gene sequences revealed a close relationship of GLRaV-2, GLRaV-3, GRSPaV, and GVA isolates from Egypt and other isolates from various geographical origins. These data are consistent with the fact that transmission of these viruses occurs predominantly through uncontrolled exchange and propagation of budwood material. Frequent exchanges of propagative grapevine materials and grafting of various combinations of scions and rootstocks create ample opportunities for different viruses and viral isolates to merge into a single vine. Afterwards, a viral complex would perpetuate in the progeny vines via large-scale vegetative propagation. This study provides an example of mixed infection and supports the imperative need to develop a network of virus-tested grapevines for national and international exchange of propagation grapevine materials. Growing certified grapevines can reduce the incidence of mixed infections and thus prevent new disease outbreaks in grape-growing regions with diverse climatic, environmental and soil conditions. It was reported that the genomic diversity of GLRaV-3 has been examined based on the analysis of partial or complete heat shock protein 70 gene (HSP70) (Turturo et al., 2005; Fuchs et al., 2009). It was reported that the genomic diversity of GVA has been examined based on the analysis of partial or complete coat protein gene (CP), because it had a certain degree of variability (Goszczynski and Jooste, 2003; Murolo et al., 2008). It was reported that the genomic diversity of GRSPaV has been examined based on the analysis of partial or complete RNA-dependent RNA polymerase gene (RdRp) (ORF 1), which is one of the most conserved regions of the GRSPaV genome (Meng et al., 1998; Lunden et al., 2010). Characterizing virus isolates is an important aspect of the development of tools for the detection of this virus, the information about sequence diversity among variants may help to select regions of the virus genome targeted for specific virus detection and to design primers for reliable detection of all known virus variants.

Acknowledgements. Special thanks to Prof. Dr. Ssa Concepcion Rubies Autonell and Dr. Claudio Ratti for their invitation to visit their Plant Virology laboratory, University of Bologna, to perform some experiments through the collaborative Italian-Egypt joint project. I would like to thank them for all the laboratory facilities and materials they provided me and for the helpful technical assistance.

\section{References}

Ahmed H, Digiaro M, Martelli G (2004): Viruses and virus diseases of grapevine in Egypt. EPPO Bulletin 34, 395-398. http:// dx.doi.org/10.1111/j.1365-2338.2004.00759.x

Alabi OJ, Martin R R, Naidu RA (2010): Sequence diversity, population genetics and potential recombination events in grapevine rupestris stem pitting-associated virus in Pacific North-West vineyards. J. Gen. Virol. 91, 265-276. http://dx.doi.org/10.1099/vir.0.014423-0

Beuve M, Sempe L, Lemaire O (2007): A sensitive one-step real-time RT-PCR method for detecting Grapevine leafroll-associated virus 2 variants in grapevine. J. Virol. Methods 141 117-124. http://dx.doi.org/10.1016/j. jviromet.2006.11.042

Craig GW, Wylie S J, Jones MG (2004): Diagnosis of plant viral pathogens. Current Science 86, 1604-1607.

Darwish HSA (2005): Studies on grapevine fanleaf virus and tomato ring spot virus on grapevine in Egypt. M.SC. Thesis, Faculty of Agriculture, Cairo University, p. 106.

Digiaro M, Martelli GP, Savino V (2000): Phloem limited viruses in the Mediterranean and Near East. Extended Abstracts 13th Meeting of ICVG, In Extended Abstracts, 13th Meeting of ICVG, March 12-18, 2000, Adelaide, Australia, 75-76. Acta Hort. 550, 37-44.

Eichmeier A. Baranek M, Pidra M (2011): The demonstration of the GFLV Nepovirus isolates on naturally infected grapevine cultivars and evaluation of variability within genome region encoding movement protein. Acta Univ. Agric. et Silvic. Mendel. Brun., LIX, No. 3, 35-44.

Engel EA, Escobar PF, Rojasa LA, Riveraa PA, Fiorec N, Valenzuela PDT (2010): A diagnostic oligonucleotide microarray for simultaneous detection of grapevine viruses. J. Virol. Methods 163, 445-451. http://dx.doi.org/10.1016/j. jviromet.2009.11.009

Fayek MA, Jomaa AH, Shalaby AA, Al-Dhaher AM (2009): Meristem tip culture for in vitro eradication of grapevine leaf rollassociated virus-1 (GLRaV-1) and grapevine fan leaf virus (GFLV) from infected flame seedless grapevine plantlets. Ini Inv. 4, 1-4.

Fenby NS, Scott NW, Slater A, Elliott MC (1995): PCR and nonisotopic labeling techniques for plant virus detection. Cell Mol. Biol. 41, 639-652.

Fiore N, Prodan S, Montealegre J, Aballay E, Pino AM, Zamorano A (2008): Survey of grapevine viruses in Chile. J. Plant. Pathol. 90, 125-130.

Fuchs M, Martinson TE, Loeb GM, Hoch HC (2009): Survey of the three major leafroll disease-associated viruses in Finger Lakes vineyards in New York. Plant Dis. 93, 395-401. http://dx.doi.org/10.1094/PDIS-93-4-0395

Gambino G, Gribaudo I (2006): Simultaneous detection of nine grapevine viruses by multiplex reverse transcriptionpolymerase chain reaction with coamplification of a plant RNA as internal control. Phytopathology 96, 1223-1229. http://dx.doi.org/10.1094/PHYTO-96-1223

Goszczynski DE, Jooste AEC (2003): Identification of grapevines infected with divergent variants of Grapevine virus A using 
variant-specific RT-PCR. J. Virol. Methods 112, 157-164. http://dx.doi.org/10.1016/S0166-0934(03)00198-8

Jarugula S, Alabi OJ, Martin RR, Naidu RA (2010): Genetic variability of natural populations of Grapevine leafroll-associated virus 2 in Pacific Northwest vineyards. Phytopathology 100, 698-707 http://dx.doi.org/10.1094/PHYTO-1007-0698

Lunden S, Meng B, Avery J, Qiu, W (2010): Association of Grapevine fanleaf virus, Tomato ringspot virus and Grapevine rupestris stem pitting-associated virus with a grapevine vein-clearing complex on var. Chardonnay. Eur. J. Plant Pathol. 126, 135-144. http://dx.doi.org/10.1007/s10658009-9527-y

MacKenzie DJ, McLean MA, Mukerji S, Green M (1997): Improved RNA extraction from woody plants for the detection of viral pathogens by reverse transcription-polymerase chain reaction. Plant Dis. 81, 222-226. http://dx.doi. org/10.1094/PDIS.1997.81.2.222

Martelli G P, Boudon-Padieu E (2006): Directory of Infectious Diseases of Grapevines and Viruses and Virus-like Diseases of the Grapevine. Bibliographic Report 1998-2004. Options Méditerranéennes B55.

Meng B, Pang SZ, Forsline PL, McFerson JR, Gonsalves D (1998): Nucleotide sequence and genome structure of grapevine rupestris stem pitting associated virus-1 reveal similarities to apple stem pitting virus. J. Gen. Virol. 79, 2059-2069.

Minafra A, Hadidi A (1994): Sensitive detection of grapevine virus A, B, or leafroll associated III from viruliferous mealybugs and infected tissue by cDNA amplification. J. Virol. Methods 47, 175-187. http://dx.doi.org/10.1016/01660934(94)90076-0

Murolo S, Romanazzi G, Rowhani A, Minafra A, La Notte P, Branzanti MB Savino V (2008): Genetic variability and population structure of Grapevine virus A coat protein gene from naturally infected Italian vines. Eur. J. Plant Pathol. 120, 137-144. http://dx.doi.org/10.1007/s10658007-9202-0

Osman F, Leutenegger C, Golino D, Rowhani A (2007): Real-time RT-PCR (TaqMan ${ }^{\star}$ ) assays for the detection of Grapevine leafroll associated viruses 1-5 and 9. J. Virol. Methods 141, 22-29. http://dx.doi.org/10.1016/j.jviromet.2006.11.035

Osman F, Leutenegger C, Golino D, Rowhani A (2008): Comparison of low-density arrays, RT-PCR and real-time TaqMan RT-PCR in detection of grapevine viruses. J. Virol. Methods 149, 292-299. http://dx.doi.org/10.1016/j. jviromet.2008.01.012

Rayapati AN, O'Neil S, Walsh D (2008): Grapevine leafroll disease. WSU Ext. Bull. EB2027E. http://cru.cahe.wsu.edu/CEPublications/eb2027e/eb2027e.pdf.
Rowhani A, Uyemoto JK, Golino DA, Martelli GP (2005): Pathogen testing and certification of Vitis and Prunus species. Ann. Rev. Phytopathol. 43, 261-278. http://dx.doi.org/10.1146/ annurev.phyto.43.040204.135919

Sabanadzovic S, Saldarelli P, Savino V (1996): Molecular diagnosis of grapevine fleck virus. Vitis 35, 137-140.

Salem N, Mansour A, Al-Musa A, Misbeh S (2007): Survey of Grapevine Viruses in Jordan. Agricultural Sciences, 34, 25-33.

Tamura K, Dudley, J, Nei M, Kumar S (2007): MEGA4: molecular evolutionary genetics analysis (MEGA) software version 4.0. Mol. Biol. Evol. 24, 1596-1599. http://dx.doi. org $/ 10.1093 / \mathrm{molbev} / \mathrm{msm} 092$

Thompson JD, Higgins DG, Gibson TJ (1994): ClustalW: improving the sensitivity of progressive multiple sequence alignment through sequence weighting, position-specific gap penalties and weight matrix choice. Nucleic Acids Res. 22, 4673-4680. http://dx.doi.org/10.1093/nar/22.22.4673

Tolba MA, El-Kady,MAS (1991): Grapevine fanleaf virus in Egypt. Extended abstracts 10th Meeting of ICGV, p.111.ICGV, Volos (GR).

Turturo C, Saldarelli P, Yafeng D, Digiaro M, Minafra A, Savino V, Martelli GP (2005): Genetic variability and population structure of Grapevine leafroll-associated virus 3 isolates. J. Gen. Virol. 86, 217-224. http://dx.doi.org/10.1099/ vir.0.80395-0

Wang J, Sharma AM, Duffy S, Almeida RPP (2011): Genetic diversity in the 3 ' terminal $4.7-\mathrm{kb}$ region of Grapevine leafroll-associated virus 3. Phytopathology 101, 445-450. http://dx.doi.org/10.1094/PHYTO-07-10-0173

Wetzel T, Jardak R, Meunier L, Ghorbel A, Reustle GM, Krczal G (2002): Simultaneous RT/PCR detection and differentiation of arabis mosaic and grapevine fanleaf nepoviruses in grapevines with a single pair of primers. J. Virol. Methods 101, 63-69. http://dx.doi.org/10.1016/ $\underline{\text { S0166-0934(01)00422-0 }}$

Youssef SA, Abou El-Ella, AM, Amer MA, Shalaby AA (2007): Detection and partial sequence identification of grapevine leafroll-associated virus-1 in Egypt. Arab J. Biotech. 2, 399-408.

Youssef SA, Al-Dhaher MA, Shalaby AA (2009): Elimination of grapevine fanleaf virus (GFLV) and grapevine leaf rollassociatedvirus-1 (GLRaV-1) from infected Grapevine plants using Meristem Tip Culture. Intern. J. Virol. 5, 89-99. http://dx.doi.org/10.3923/ijv.2009.89.99 